\title{
Pengaruh Perbandingan Modified Cassava Flour (Mocaf) dan Puree Labu Kuning (Cucurbita Moschata) Terhadap Karakteristik Brownies Kukus
}

\author{
The Effect Comparison of Modified Cassava Flour (Mocaf) \\ and Puree Pumpkin (Cucurbita moschata) to the Characteristics of Steamed \\ Brownies
}

\author{
I Gusti Agung Anggi Putri Arina ${ }^{1}$, Putu Timur Ina ${ }^{1 *}$, Gusti Ayu Ekawati ${ }^{1}$ \\ Program Studi Teknologi Pangan, Fakultas Teknologi Pertanian, \\ Universitas Udayana, Kampus Bukit Jimbaran, Badung-Bali \\ Penulis korespondensi: P.Timur Ina, Email: timurina@unud.ac.id
}

\begin{abstract}
The study aims to determine the effect comparison of mocaf with pumpkin puree to the characteristics of steamed brownies and to find out the best comparison mocaf with pumpkin puree to produce brownies with the best characteristics. The experimental design used in this research was a Completely Randomized Design (CRD) with a comparison of mocaf and puree of pumpkin consisting of 5 treatments namely: 100\%: $0 \%$; 90\%: 10\%; 80\%: 20\%; 70\%: 30\%; 60\%: 40\%. The treatment was repeated 3 times so that they were obtained 15 experimental units. The data obtained were analyzed by variance and if the treatment had significant effect then followed by Duncan's Multiple Range Test (DMRT). Comparison of mocaf and pumpkin puree affected water content, $\beta$-carotene, $\beta$-carotene bleaching, hedonic test (color, texture, aroma, taste and overall rate) and scoring test (texture). Ratio of $60 \%$ mocaf and $40 \%$ puree of pumpkin had the best characteristics with water content of $34,49 \%$, ash content of $1,10 \%, \beta$-carotene of $6,82 \mathrm{mg} / 100 \mathrm{~g}, \beta$ carotene bleaching of $1,34 \mathrm{mg} / \mathrm{ml}$, the texture was liked and very soft, the color, aroma, taste and the fullness of acceptance was liked.
\end{abstract}

Keywords : steamed brownies, mocaf, puree of pumpkin

\section{PENDAHULUAN}

Brownies kukus adalah sejenis cake coklat padat yang awalnya merupakan adonan gagal dan keras (Ayu et al., 2019). Brownies dapat dikategorikan menjadi dua, yaitu brownies panggang dan brownies kukus. Berdasarkan penelitian dari Saragih (2011), secara umum tidak terdapat perbedaan diantara keduanya. Perbedaannya terletak pada kandungan kadar air di dalamnya. Brownies kukus memiliki kadar air yang lebih tinggi dibanding brownies panggang sehingga memiliki daya simpan yang lebih singkat. Salah satu bahan utama pembuatan brownies adalah cooking chocolate compound. Jenis chocolate compound yang sering digunakan untuk pembuatan brownies adalah dark chocolate, milk chocolate, dan white chocolate. Di pasaran banyak sekali berkembang brownies dengan aneka kreasi dan rasa yang ternyata banyak disukai para pecintanya seperti brownies green tea, brownies nangka, brownies ubi ungu dan sebagainya.

Bahan utama pembuatan brownies yang sudah umum adalah terigu, namun 
terigu adalah produk impor karena budidayanya di Indonesia belum begitu berkembang. Terigu juga mengandung gluten yang tidak semua orang dapat mengkonsumsi dan mencerna gluten dengan baik. Orang yang penyandang intoleransi gluten dan autism spectrum disorder (ASD) harus menghindari gluten agar tidak timbul dampak buruk pada tubuh (Yustisia, 2013). Upaya diversifikasi pangan penting dilakukan, selain untuk mengurangi ketergantungan pada terigu, juga untuk menggali potensi pangan lokal.

Umbi-umbian merupakan salah satu sumber karbohidrat dari pangan lokal yang dapat digunakan sebagai makanan pokok yang bebas gluten, salah satunya adalah singkong. Pengembangan bahan pangan lokal singkong yang dimodifikasi dengan perlakuan fermentasi lalu diolah menjadi tepung, dikenal dengan nama mocaf (Salim, 2011). Mocaf memiliki karakteristik berwarna putih, tidak berbau singkong dan bisa diolah menjadi makanan, contohnya cookies, cake, roti, kue basah dan mie. Keunggulan mocaf yaitu kandungan kalsium yang lebih tinggi dibandingkan dengan gandum serta tidak memiliki kandungan gluten. Kelemahan mocaf yaitu memiliki kandungan antioksidan yang rendah, dimana dewasa ini antioksidan sangat diperlukan untuk kesehatan tubuh sehingga perlu ditambahkan dengan labu kuning yang kaya akan betakaroten dan dapat digunakan sebagai antioksidan.
Labu kuning (Cucurbita moschata) merupakan jenis tanaman sayur-sayuran yang memiliki tingkat produksi relatif tinggi di Indonesia. Menurut Data Badan Pusat Statistik dalam Fatdhilah (2014) menunjukan hasil rata-rata produksi labu kuning seluruh Indonesia berkisar antara 2021 ton per hektar sedangkan konsumsi labu kuning di Indonesia masih sangat rendah, yakni kurang dari $50 \mathrm{~kg}$ perkapita pertahun. Harga labu kuning juga cukup terjangkau dan mudah dijumpai di pasaran, selain itu labu kuning juga memiliki banyak manfaat yang dapat ditinjau dari kandungan gizinya. Pada penelitian ini menggunakan puree dari labu kuning karena dilihat dari proses pembuatan puree labu kuning jauh lebih mudah dibandingkan pembuatan tepung labu kuning.

Labu kuning dikenal kaya akan karotenoid yang berfungsi sebagai antioksidan. Beta karoten merupakan salah satu jenis karotenoid, di samping mempunyai aktivitas biologis sebagai provitamin-A, juga dapat berperan sebagai antioksidan yang efektif pada konsentrasi oksigen rendah (Sinaga, 2011). Labu kuning dikenal kaya zat gizi seperti vitamin A (180 SI), vitamin C (52 mg per $100 \mathrm{~g}$ ), besi $(1,4$ mg per $100 \mathrm{~g}$ ) dan karbohidrat sebagai sumber serat $(6,6 \mathrm{mg}$ per $100 \mathrm{~g})$, serta mengandung provitamin A nabati berupa beta karoten sebesar $767 \mu \mathrm{g} / \mathrm{g}$ bahan (Gardjito et al, 2006). Hasil penelitian Ginting (2011) menunjukkan konsumsi satu 
gram labu kuning dapat mensuplai $17.5 \mu \mathrm{g}$ beta karoten atau sama dengan 1.46 RE (12 $\mu \mathrm{g}$ beta karoten sama dengan 1 Retinol Equivalent). Di Indonesia angka kecukupan gizi untuk beta-karoten berdasarkan Keputusan Kepala BPOM RI (2003), untuk orang dewasa adalah $3600 \mu \mathrm{g}$ dan untuk anak balita adalah $2400 \mu \mathrm{g}$. Beta karoten berfungsi sebagai antioksidan yang dapat mengurangi serta mencegah resiko penyakit jantung dan kanker.

\section{METODE PENELITIAN}

\section{Bahan dan Alat}

Bahan-bahan yang digunakan dalam melaksanakan penelitian ini terdiri dari bahan baku, bahan tambahan, dan bahan kimia. Bahan baku terdiri dari labu kuning jenis bokor yang diperoleh dari Singaraja dan mocaf (Pelangi) yang diperoleh dari toko Fenny Denpasar, sedangkan bahan tambahan terdiri dari telur ayam, white chocolate (Tulip), margarin (Blue Band), ovalet (Kopoekopoe), gula pasir (Gulaku) diperoleh dari toko Fenny. Bahan kimia yang digunakan dalam melakukan analisis meliputi aseton, Na2SO4, aquades, kloroform, etanol, petroleum benzene, $\beta$ karoten dan asam linoleat.

Alat-alat yang digunakan dalam penelitian ini terdiri dari mixer, waskom, timbangan analitik (Scout pro dan Adventurer OHAUS), spatula, loyang brownies, panci kukus, kompor gas, sendok, pisau, lumpang, Erlenmeyer (Pyrex), labu ukur (Pyrex), labu pemisah (Pyrex), oven
(Memmert), spektrofotometer (Genesys $15 \mathrm{~s}$ $U$ v-Vis), kuvet, batang pengaduk, cawan poselin, tabung reaksi (Pyrex), vortex (Maxi mix II), kompor listrik, ayakan, muffle furnace (Daihan), pipet tetes, pipet volume, desikator dan aluminium foil.

\section{Pelaksanaan penelitian}

\section{Pembuatan puree labu kuning.}

Labu kuning disortasi, dikupas dan dihilangkan bijinya setelah itu dipotong dengan ukuran kotak $5 \times 5 \times 5 \mathrm{~cm}$ dan dicuci. Lalu kemudian dikukus pada suhu $100^{\circ} \mathrm{C}$ selama 10 menit. Setelah dingin labu kuning dihancurkan dengan blender hingga menjadi puree labu kuning.

\section{Pembuatan brownies kukus}

Proses pembuatan brownies kukus sebagai berikut. Gula pasir, telur dan ovalet dicampur dengan mixer selama 15 menit. Dimasukkan mocaf dan puree labu kuning (sesuai perlakuan) dan dicampur dengan mixer sampai rata. Selanjutnya margarin dan coklat putih yang sudah dilelehkan diaduk bersama adonan dengan menggunakan spatula. Adonan brownies dimasukkan ke dalam cetakan lalu dikukus selama 30 menit pada suhu $100^{\circ} \mathrm{C}$.

\section{HASIL DAN PEMBAHASAN}

Nilai rata-rata kadar air, kadar abu, dan $\beta$-karoten dari bahan baku mocaf dan puree labu kuning dapat dilihat pada Tabel 1 dan nilai rata-rata kadar air, kadar abu, $\beta$ karoten, dan $\beta$-karoten bleaching dari brownies kukus dapat dilihat pada Tabel 2. Puree labu kuning dari hasil penelitian 
memiliki kadar air 89,09\%, kadar abu 0,73\%

dan $\beta$-karoten $21,20 \mathrm{mg} / 100 \mathrm{~g}$, sedangkan mocaf memiliki kadar air 9,33\%, kadar abu $0,62 \%$, dan $\beta$-Karoten $0,77 \mathrm{mg} / 100 \mathrm{~g}$.

Tabel 1. Nilai rata-rata kadar air, kadar abu, dan $\beta$-karoten mocaf dan puree labu kuning.

\begin{tabular}{ccc}
\hline Uji & Mocaf & Puree Labu Kuning \\
\hline Kadar Air (\%) & 9,33 & 89,09 \\
Kadar Abu (\%) & 0,62 & 0,73 \\
$\beta$-Karoten (mg/100g) & 0,77 & 21,20 \\
\hline
\end{tabular}

Tabel 2. Nilai rata-rata kadar air, kadar abu, $\beta$-karoten dan $\beta$-karoten bleaching brownies kukus.

\begin{tabular}{ccccc}
\hline $\begin{array}{c}\text { Perlakuan } \\
(\mathrm{M}: \text { PLK })\end{array}$ & $\begin{array}{c}\text { Kadar Air } \\
(\%)\end{array}$ & $\begin{array}{c}\text { Kadar Abu } \\
(\%)\end{array}$ & $\begin{array}{c}\beta \text {-Karoten } \\
(\mathrm{mg} / 100 \mathrm{~g})\end{array}$ & $\begin{array}{c}\beta \text {-Karoten } \\
\text { Bleaching } \\
(\mathrm{mg} / \mathrm{ml})\end{array}$ \\
\hline P0 (100:0) & $20.61 \pm 1.59 \mathrm{e}$ & $0.91 \pm 0.15 \mathrm{a}$ & $2,28 \pm 0,25 \mathrm{e}$ & $9,40 \pm 0,14 \mathrm{a}$ \\
P1 (90:10) & $28.40 \pm 0.65 \mathrm{~d}$ & $0.95 \pm 0.18 \mathrm{a}$ & $4,42 \pm 0,29 \mathrm{~d}$ & $6,54 \pm 0,13 \mathrm{~b}$ \\
P2 (80:20) & $30.16 \pm 0.26 \mathrm{c}$ & $0.99 \pm 0.09 \mathrm{a}$ & $5,31 \pm 0,17 \mathrm{c}$ & $5,14 \pm 0,02 \mathrm{c}$ \\
P3 (70:30) & $32.18 \pm 0.17 \mathrm{~b}$ & $1.05 \pm 0.03 \mathrm{a}$ & $6,22 \pm 0,09 \mathrm{~b}$ & $3,56 \pm 0,20 \mathrm{~d}$ \\
P4 (60:40) & $34.49 \pm 0.26 \mathrm{a}$ & $1.10 \pm 0.21 \mathrm{a}$ & $6,82 \pm 0,10 \mathrm{a}$ & $1,34 \pm 0,10 \mathrm{e}$ \\
\hline Keterangan: Nilai rata - rata yang diikuti oleh huruf yang sama pada kolom yang sama menunjukkan \\
berbeda tidak nyata(P>0,05). \\
M = Mocaf \\
PLK $=$ Puree Labu Kuning
\end{tabular}

\section{Kadar Air}

Hasil sidik ragam menunjukkan bahwa perbandingan mocaf dan puree labu kuning berpengaruh sangat nyata $(\mathrm{P}<0,01)$ terhadap kadar air dari brownies kukus. Kadar air terendah diperoleh pada perlakuan P0 (100\% mocaf) yaitu $20,61 \%$, sedangkan kadar air tertinggi diperoleh pada perlakuan P4 (60\% mocaf dan 40\% puree labu kuning) yaitu sebesar 34,49\% (Tabel 2). Brownies kukus dengan penambahan puree labu kuning yang semakin meningkat menghasilkan kadar air yang semakin tinggi. Hal ini disebabkan oleh puree labu kuning yang memiliki kadar air yang lebih tinggi dibandingkan mocaf. Berdasarkan hasil analisis bahan baku, kadar air pada puree labu kuning yaitu 89,09\%, sedangkan kadar air pada mocaf sebesar $9,33 \%$.

\section{Kadar Abu}

Berdasarkan hasil sidik ragam dapat dilihat bahwa perbandingan mocaf dan puree labu kuning berpengaruh tidak nyata $(\mathrm{P}>0,05)$ terhadap kadar abu dari brownies.

Tabel 2, menunjukkan kadar abu pada brownies kukus berkisar antara 0,91\% sampai dengan $1,10 \%$. Hal ini disebabkan karena pada hasil analisis bahan baku kadar abu dari puree labu kuning tidak berbeda 
jauh dengan mocaf. Tabel 1 menunjukkan kadar abu pada puree labu kuning sebesar 0,73\% dan kadar abu pada mocaf adalah 0,62\%. Menurut Pandoyo (2000), kandungan mineral dalam bahan pangan dapat diperkirakan sebagai kandungan abu yang merupakan residu anorganik setelah bahan-bahan organik terbakar habis.

\section{$\beta$-Karoten}

Hasil sidik ragam menunjukkan bahwa perbandingan mocaf dan puree labu kuning berpengaruh sangat nyata $(\mathrm{P}<0,01)$ terhadap $\beta$-karoten brownies kukus. $\beta$ - karoten brownies kukus berkisar antara 2,28 $\mathrm{mg} / 100 \mathrm{~g}$ sampai dengan $6,82 \mathrm{mg} / 100 \mathrm{~g}$. $\beta$ karoten tertinggi diperoleh dari brownies kukus pada perlakuan P4 (60\% mocaf dan $40 \%$ puree labu kuning) yaitu sebesar 6,82 $\mathrm{mg} / 100 \mathrm{~g}$, sedangkan $\beta$-karoten terendah diperoleh dari brownies kukus dengan perlakuan P0 (100\% mocaf) yaitu 2,28 $\mathrm{mg} / 100 \mathrm{~g}$. Hubungan antara perbandingan mocaf dan puree labu kuning dengan $\beta$ karoten brownies kukus dapat dilihat pada Gambar 1.

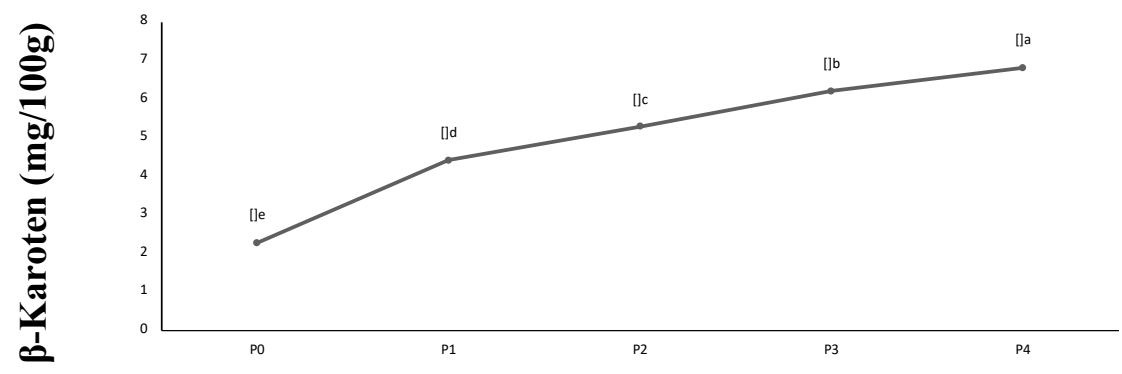

Perbandingan Mocaf dengan Puree Labu Kuning

\section{Gambar 1. Hubungan antara perbandingan mocaf : puree labu kuning dengan kadar $\beta$ - karoten brownies kukus}

Berdasarkan Gambar 1 dapat dilihat bahwa brownies kukus dengan formula penambahan puree labu kuning yang semakin meningkat menghasilkan brownies kukus dengan kadar $\beta$-karoten yang semakin tinggi. Hal ini disebabkan karena pada analisis bahan baku kadar $\beta$-karoten pada puree labu kuning jauh lebih besar dari pada mocaf yaitu sebesar 21,20 $\mathrm{mg} / 100 \mathrm{~g}$, sedangkan kadar $\beta$-karoten pada mocaf hanya sebesar $0,77 \mathrm{mg} / 100 \mathrm{~g}$. Labu kuning memiliki kandungan beta karoten yang sangat tinggi di dalam daging buahnya (Zumrotin et al., 2011). Hasil penelitian dari Ginting (2011) menunjukkan bahwa konsumsi satu gram labu kuning dapat mensuplai 17,5 $\mu \mathrm{g}$ beta karoten, sehingga labu kuning dapat dijadikan sebagai salah satu bahan pangan alternatif untuk menambah jumlah vitamin A harian yang 
dibutuhkan tubuh yaitu sekitar $500 \mathrm{RE}$ menurut AKG 2013.

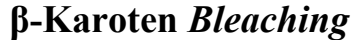

Hasil sidik ragam menunjukkan bahwa perbandingan mocaf dan puree labu kuning berpengaruh sangat nyata $(\mathrm{P}<0,01)$ terhadap $\beta$-karoten bleaching dari brownies kukus. Hubungan antara perbandingan mocaf dan puree labu kuning dengan $\beta$ karoten bleaching brownies kukus dapat dilihat pada Gambar 2.

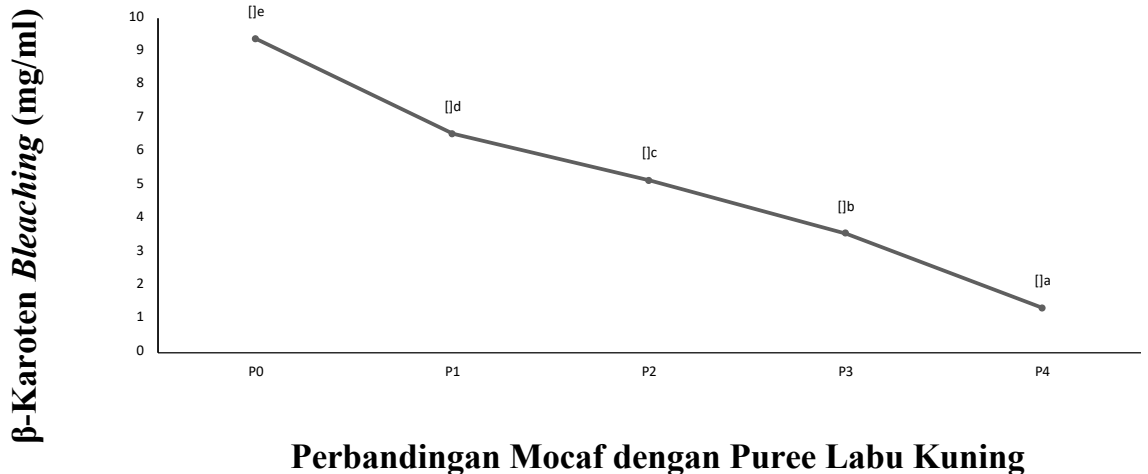

Gambar 2. Hubungan antara perbandingan mocaf : puree labu kuning dengan $\beta$-karoten bleaching brownies kukus.

$\beta$-karoten bleaching brownies kukus berkisar antara $1,34 \mathrm{mg} / \mathrm{ml}$ sampai dengan 9,40 $\mathrm{mg} / \mathrm{ml}$. Nilai $\beta$-karoten bleaching tertinggi diperoleh dari brownies kukus pada perlakuan P0 (100\% mocaf) yaitu sebesar 9,40 $\mathrm{mg} / \mathrm{ml}$, sedangkan nilai $\beta$-karoten bleaching terendah diperoleh dari brownies kukus pada perlakuan P4 (60\% mocaf dan $40 \%$ puree labu kuning) yaitu $1,34 \mathrm{mg} / \mathrm{ml}$. Berdasarkan Gambar 2 dapat dilihat bahwa brownies kukus dengan formula penambahan puree labu kuning yang semakin meningkat menghasilkan nilai $\beta$ karoten bleaching yang semakin rendah. Hubungan antara nilai $\beta$-karoten dan $\beta$ karoten bleaching berbanding terbalik, semakin tinggi nilai $\beta$-karoten yang terkandung pada brownies kukus maka semakin rendah nilai $\beta$-karoten bleaching pada brownies kukus.

Metode $\quad \beta$-karoten bleaching merupakan suatu metode untuk mengukur aktivitas antioksidan dalam menghambat peroksidasi lipid. Metode ini didasarkan pada kemampuan antioksidan untuk mencegah atau menghambat pemudaran warna jingga karoten akibat oksidasi dari radikal peroksida yang terbentuk pada reaksi oksidasi asam linoleat (Tahir et al., 2017). Tingkat oksidasi berbanding terbalik dengan kemampuan senyawa mencegah reaksi oksidasi, sehingga semakin rendah tingkat oksidasinya maka kemampuan untuk mencegah reaksi oksidasi menjadi lebih baik 
begitu pula sebaliknya. Hal ini disebabkan karena radikal bebas yang berasal dari oksidasi asam linoleat akan menyerang ikatan rangkap terkonjugasi dari beta karoten (Hadiwibowo, 2010).

\section{Sifat Sensoris}

Nilai rata-rata uji hedonik terhadap warna, tekstur, aroma, rasa dan penerimaan keseluruhan dan uji skoring terhadap tekstur brownies kukus dapat dilihat pada Tabel 3.

Tabel 3. Nilai rata-rata uji hedonik warna, aroma, tekstur, rasa, penerimaan keseluruhan dan uji skoring tekstur brownies kukus

\begin{tabular}{ccccccc}
\hline & \multicolumn{6}{c}{ Nilai rata - rata uji sensoris } \\
\cline { 2 - 7 } $\begin{array}{c}\text { Perlakuan } \\
\text { (M:PLK) }\end{array}$ & $\begin{array}{c}\text { Warna } \\
\text { (Hedonik) }\end{array}$ & $\begin{array}{c}\text { Tekstur } \\
\text { (Hedonik) }\end{array}$ & $\begin{array}{c}\text { Aroma } \\
\text { (Hedonik) }\end{array}$ & $\begin{array}{c}\text { Rasa } \\
\text { (Hedonik) }\end{array}$ & $\begin{array}{c}\text { Penerimaan } \\
\text { Keseluruhan } \\
\text { (Hedonik) }\end{array}$ & $\begin{array}{c}\text { Tekstur } \\
\text { (Skoring) }\end{array}$ \\
\hline P0 (100\%:0\%) & $2,90 \mathrm{c}$ & $3,15 \mathrm{~b}$ & $3,70 \mathrm{~b}$ & $3,50 \mathrm{~b}$ & $3,30 \mathrm{~b}$ & $1,80 \mathrm{c}$ \\
P1 (90\%:10\%) & $3,35 \mathrm{bc}$ & $3,85 \mathrm{a}$ & $3,90 \mathrm{ab}$ & $3,70 \mathrm{ab}$ & $3,70 \mathrm{ab}$ & $2,25 \mathrm{~b}$ \\
P2 (80\%:20\%) & $4,05 \mathrm{a}$ & $3,85 \mathrm{a}$ & $4,25 \mathrm{a}$ & $3,80 \mathrm{ab}$ & $3,95 \mathrm{a}$ & $2,35 \mathrm{~b}$ \\
P3 (70\%:30\%) & $4,10 \mathrm{a}$ & $4,10 \mathrm{a}$ & $4,05 \mathrm{ab}$ & $4,25 \mathrm{a}$ & $4,20 \mathrm{a}$ & $2,90 \mathrm{a}$ \\
P4 (60\%:40\%) & $3,60 \mathrm{ab}$ & $4,00 \mathrm{a}$ & $4,05 \mathrm{ab}$ & $3,95 \mathrm{ab}$ & $3,85 \mathrm{ab}$ & $2,70 \mathrm{a}$ \\
\hline
\end{tabular}

Keterangan : Nilai rata - rata yang diikuti oleh huruf yang sama pada kolom yang sama menunjukkan perlakuan yang berbeda tidak nyata $(\mathrm{P}>0,05)$.

$\mathrm{M}=$ Mocaf

PLK $=$ Puree Labu Kuning

Kriteria hedonik : 1 (sangat tidak suka), 2 (tidak suka), 3 (biasa), 4 (suka), 5 (sangat suka).

Kriteria skoring : 1 (tidak lembut), 2 (lembut), 3 (sangat lembut).

\section{Warna}

Berdasarkan hasil sidik ragam menunjukkan bahwa perbandingan mocaf dan puree labu kuning berpengaruh sangat nyata $(\mathrm{P}<0,01)$ terhadap warna (uji hedonik) brownies kukus. Berdasarkan Tabel 3, perlakuan dengan nilai terendah diperoleh pada P0 dengan nilai 2,90 (biasa), dan perlakuan dengan nilai tertinggi diperoleh pada P3 dengan nilai 4,10 (suka) dan berbeda tidak nyata dengan P2 dan P4. Semakin tinggi penambahan puree labu kuning maka penerimaan terhadap warna semakin disukai, hal ini disebabkan oleh warna yang dihasilkan oleh puree labu kuning. Puree labu kuning mengandung pigmen karotenoid yang tinggi pada daging buahnya (Anam dan Handajani, 2010). Pigmen karotenoid merupakan pigmen alami berwarna kuning kemerahan yang terdapat pada buah-buahan dan sayuran.

Winarno (2004) menyatakan bahwa warna merupakan komponen yang sangat penting untuk menentukan kualitas atau derajat penerimaan suatu bahan pangan. Suatu bahan pangan meskipun dinilai enak dan teksturnya sangat baik, tetapi memiliki warna yang tidak menarik atau memberi kesan telah menyimpang dari warna yang seharusnya maka bahan tersebut tidak akan dikonsumsi. 


\section{Tekstur}

Berdasarkan data hasil sidik ragam menunjukkan bahwa perbandingan mocaf dan puree labu kuning berpengaruh nyata $(\mathrm{P}<0,05)$ terhadap tekstur (uji hedonik) brownies kukus. Berdasarkan Tabel 3, perlakuan dengan nilai tertinggi diperoleh pada P3 dengan nilai 4,10 (suka) dan berbeda tidak nyata dengan P1, P2 dan P4, sebaliknya perlakuan dengan nilai terendah diperoleh pada P0 dengan nilai 3,15 (biasa).

Berdasarkan data hasil sidik ragam menunjukkan bahwa perbandingan mocaf dan puree labu kuning berpengaruh sangat nyata $(\mathrm{P}<0,01)$ terhadap kesukaan tekstur (uji skoring) brownies kukus. Berdasarkan Tabel 3, perlakuan dengan nilai tertinggi diperoleh pada P3 dengan nilai 2,90 (sangat lembut) dan berbeda tidak nyata dengan P4, dan perlakuan dengan nilai terendah diperoleh pada P0 dengan nilai 1,80 (lembut). Semakin tinggi penambahan puree labu kuning menghasilkan brownies kukus dengan tekstur yang sangat lembut, hal ini disebabkan oleh kadar air yang terkandung pada brownies kukus dimana dapat dilihat pada Tabel 3 semakin tinggi penambahan puree labu kuning menghasilkan brownies kukus dengan kadar air yang semakin tinggi.

\section{Aroma}

Berdasarkan hasil sidik ragam menunjukkan bahwa perbandingan mocaf dan puree labu kuning berpengaruh nyata $(\mathrm{P}<0,05)$ terhadap aroma (uji hedonik) brownies kukus. Berdasarkan Tabel 3, perlakuan dengan nilai tertinggi diperoleh pada P2 dengan nilai 4,25 (suka) dan tidak berbeda dengan P1, P3 dan P4, sedangkan perlakuan dengan nilai terendah diperoleh pada P0 dengan nilai 3,70 (suka). Hartatie (2011) menyatakan bahwa bahan-bahan yang digunakan untuk penelitian sudah melalui proses pengujian kualitas sehingga merupakan bahan-bahan yang berkualitas baik sehingga tidak terdapat penyimpangan aroma dari bahan-bahan tersebut seperti aroma tengik, pahit, sangit (coocked flavor), metalik dan sebagainya.

\section{Rasa}

Berdasarkan hasil sidik ragam menunjukkan bahwa perbandingan mocaf dan puree labu kuning berpengaruh nyata $(\mathrm{P}<0,05)$ terhadap rasa (uji hedonik) brownies kukus. Berdasarkan Tabel 3, perlakuan dengan nilai tertinggi diperoleh pada P3 dengan nilai 4,25 (suka) dan tidak berbeda dengan P1, P2 dan P4, sebaliknya perlakuan dengan nilai terendah diperoleh pada P0 dengan nilai 3,50 (biasa). Khasanah (2003) menyatakan bahwa rasa timbul karena rangsangan kimiawi yang dapat diterima oleh indera pencicip atau lidah dan merupakan faktor yang dinilai panelis setelah warna, tekstur, dan aroma yang dapat mempengaruhi penerimaan produk pangan. Rasa yang enak dapat menarik perhatian sehingga konsumen lebih cenderung menyukai makanan dari rasanya. Jika komponen aroma, warna dan tekstur baik tetapi konsumen tidak menyukai rasanya 
maka konsumen tidak akan menerima produk pangan tersebut.

\section{Penerimaan Keseluruhan}

Berdasarkan hasil sidik ragam menunjukkan bahwa perbandingan mocaf dan puree labu kuning berpengaruh nyata $(\mathrm{P}<0,05)$ terhadap penerimaan keseluruhan brownies kukus. Berdasarkan Tabel 3, perlakuan dengan nilai tertinggi diperoleh pada P3 dengan nilai 4,20 (suka) dan tidak berbeda dengan P1, P2 dan P4, sedangkan perlakuan dengan nilai terendah diperoleh pada P0 dengan nilai 3,30 (biasa). Penerimaan keseluruhan brownies kukus dipengaruhi oleh beberapa faktor seperti warna, aroma, tekstur, dan rasa.

\section{KESIMPULAN}

Berdasarkan hasil penelitian ini dapat disimpulkan perbandingan mocaf dan puree labu kuning berpengaruh terhadap kadar air, kadar abu, $\beta$-karoten, $\beta$-karoten bleaching, uji hedonik (warna, aroma, rasa, tekstur dan penerimaan keseluruhan) dan uji skoring (tekstur). Perbandingan 60\% mocaf dengan $40 \%$ puree labu kuning menghasilkan brownies kukus dengan karakteristik terbaik yaitu: kadar air $34,49 \%$, kadar abu $1,10 \%, \beta$ karoten $6,82 \mathrm{mg} / 100 \mathrm{~g}, \beta$-karoten bleaching $1,34 \mathrm{mg} / \mathrm{ml}$, warna, tekstur, aroma, rasa dan penerimaan kesuluruhan disukai.

\section{DAFTAR PUSTAKA}

Ayu H., A. Ekawati, dan W. Wisaniyasa. 2019. Perbandingan mocaf dengan tepung kacang merah dalam pembuatan brownies kukus gluten free casein free (GFCF). Jurnal Ilmu dan Teknologi Pangan. 8 (1) : 1-7.

Aznam, N. dan I. Amanah. 2016. Penentuan kadar total fenol dan uji aktivitas antioksidan kombinasi ekstrak sarang semut (Myrmecodia pendens Merr. \& L.M. Perry) dan ekstrak kencur (Kaempferia galanga Linn.) dengan metode $\beta$-carotene bleaching. Jurnal Kimia Dasar. 21 (3) : 1-9

Fatdhilah, N. 2014. Pengaruh Jumlah Maltodekstrin dan Lama Pengeringan Terhadap Sifat Ogranoleptik Sup Labu Kuning Instan. Skirpsi. Tidak Dipublikasikan. Fakultas Teknik, UNESA, Surabaya.

Gardjito M., M. Agnes, dan A. Nur. 2006. Mikroenkapsulasi betakaroten buah labu kuning dengan enkapsulan whey dan karbohidrat. Jurnal Teknologi Pertanian Universitas Mulawarman. 2(1): 13-18.

Ginting, L.N. 2011. Karakteritik Beberapa Labu Kuning. Skripsi. Tidak Dipublikasikan. Fakultas Pertanian, USU, Medan.

Gomez, K. A. dan A. A. Gomez. 1995. Prosedur Statistik Untuk Penelitian Pertanian. UI Press. Jakarta

Hadiwibowo, T. 2010. Penentuan Aktivitas Antioksidan Ekstrak Etanol Daun Bandotan (Ageratum conyziodes L.) Melalui Ekstraksi Gelombang Mikro. Skripsi. Fakultas Teknik. Universitas Indonesia. Depok.

Hartatie, E. S. 2011. Kajian formulasi (bahan baku, bahan pemantap) dan metode pembuatan terhadap kualitas es krim. Jurnal Gamma. 7(1): 20-26.

Khasanah, U. 2003. Formulasi Karakterisasi Fisiko-Kimia dan Organoleptik Produk Makanan Sarapan Ubi Jalar (Sweet Potato Flakes). Skripsi. Tidak dipublikasi . Fakultas Teknologi Pertanian. Institut Pertanian Bogor, Bogor.

Nielsen, S. 1995. Introduction to The Chemical Analysis of Food.Chapman and Hall. New York. USA.

Pandoyo, S.T. 2000. Pembuatan Keripik Pepaya Dengan Vacum Friying, Kajian 
Dari Lama Perendaman Dalam Larutan $\mathrm{CaCl} 2$ dan Lama Pembekuan Terhadap Sifat Fisik Kimia dan Organoleptik. Skripsi. Universitas Brawijaya. Malang.

Salim, E. 2011. Mengolah Singkong Menjadi tepung Mocaf Bisnis Produk Alternatif Pengganti Terigu. Yogyakarta: Lily Publisher.

Saragih, I.P. 2011. Penentuan Kadar Air Pada Cake Brownies dan Roti Two In One Nenas dan Es. Skripsi. Tidak Dipublikasikan. USU, Medan.

Soekarto, S.T. 1985. Penilaian Organoleptik Untuk Industri Pangan dan Pertanian. Bharata Karya Aksara. Jakarta.

Sudarmadji, S. B. Haryono dan Suhardi. 1997. Prosedur Analisa Untuk Bahan Makanan dan Pertanian. Liberty. Yogyakarta.
Tahir, M., Z. Abidin, dan N. Sukmawati. 2017. Antioxidant activityof hydrolyzed black soybean (Glycine Soja Linn. Sieb.) by $\beta$-carotene bleacing. Journal of Pharmaceutical and Medicinal Sciences. Vol. 2(1): 1-4.

Winarno, F. G. 2004. Hasil-hasil Simposium Penganekaragaman Pangan. Prakarsa Swasta dan Pemda. Jakarta.

Yustisia, R. 2013. Pengaruh penambahan telur terhadap kadar protein, serat, tingkat kekenyalan dan penerimaan mie basah bebas gluten berbahan baku tepung komposit. Journal of Nutrition College. 2 (4): 697-703.

Zumrotin, H., M. Sugitha dan M. Indri. 2017. Pengaruh perbandingan puree labu kuning (Cucurbita moschata ex. Poir) dan tapioka terhadap karakteristik bika ambon. Jurnal Ilmu dan Teknologi Pangan. 5 (2) : 153-161. 